\title{
IMPACT OF THE BELT AND ROAD INITIATIVE ON WORLD POLITICS AND ECONOMY
}

\author{
Sheriff Ghali Ibrahim, Thomas Agbor and Ahmet Arabaci \\ Department of Political Science and International relations, Nile University of Nigeria \\ Email: sherfboy@yahoo.com; Phone: +234-7063372013
}

Cite this article:

Sheriff G.I., Thomas A., Ahmet A. (2021), Impact of the Belt and Road Initiative on World Politics and Economy. African Journal of Economics and Sustainable Development 4(2), 96-103. DOI: 10.52589/AJESDVKSRVVIC

\section{Manuscript History}

Received: 29 June 2021

Accepted: 27 July 2021

Published: 9 Aug 2021

Copyright $\odot 2020$ The Author(s). This is an Open Access article distributed under the terms of Creative Commons AttributionNonCommercial-NoDerivatives 4.0 International (CC BY-NC-ND 4.0 ), which permits anyone to share, use, reproduce and redistribute in any medium, provided the original author and source are credited.
ABSTRACT: This paper aims at focusing on the main impact of the China belt and road initiative on world politics and economic development. Given that the BRI is a foreign policy launched by the Chinese government under the leadership of President $X i$, and this time on a large scale with a plethora of impacts designed to build a network of mutually benefiting economic activities among the China neighbours across the Eurasian continent and the maritime routes between China and Europe, with plans to extend to Africa. The collaborative efforts of this initiative would expand global trade and increase economic development among the countries within the One Belt, One Road area. The initiative also presents scepticisms, uncertainties and concerns among political elites, offering observers the outlook of the advantage the initiative offers the Chinese at the expense of developing countries. The paper uses the secondary data methodological approach in presenting its reviewed literature. The paper adopts the theories of geopolitics that explain the political power linked to geographical space that comprises water and land as its territories. The objective of the Belt and Road Initiative is to enhance the connectivity of infrastructure, trade liberalization, and global financial integration. The article investigates the development of the project from global political, geographical, economical and international relations perspectives.

KEYWORDS: BRI, World Politics, Economy, Global trade, Leadership, Geopolitics 


\section{INTRODUCTION}

Following the revolution of 1966-1967, the People's Republic of China (PRC) reformed its economic policies in 1978, and ever since, there has been the unceasing success of economic growth and market expansion. In China's remarkable journey to economic development, the country had remarkably lifted 850 million people out of poverty (World Bank, 2019). China is now the second-largest economy globally, with an outstanding population of 1.3 billion people and a GDP of 13.4 trillion USD and the single most significant contributor of world growth since 2008 (World Bank, 2019). China has also surpassed the largest economy of the world United States of America (USA) in some aspects such as in exportation, which makes China the largest exporter of goods and services worldwide. A lot of political analysts believe that the unipolarity of the world being led by the USA is fast reaching its decline with the rise of Chinaled economic alliances (Sears, 2016; Vuving, 2012).

In the context of this article, China plans to build the largest infrastructure project ever in human history which has been a topic of debate and interest in world politics. China's Belt and Road Initiative (BRI) is an ambitious project which cuts across different continents mainly Asia to Europe and Africa through land and waterways. Since it was first suggested by President Xi in 2013, it has spurred a lot of speculation among different scholars and policymakers around the world (Sarker, 2019, p280). The significance of the One Belt, One Road initiative is recommended by the way that Beijing announced in late March 2015 that it had set up "an extraordinary driving group to manage the execution of the Belt and Road initiatives." The assertion said the main group would be accountable for "directing and coordinating business related to the initiative. However, it didn't indicate its individuals." The office of the group was set under the National Development and Reform Commission (NDRC), China's top economic organizer.

The extension and substance of the One Belt, One Road initiative is fairly amazing, and its objectives are very driven. One authoritative source fights that the initiative ought to advance five significant objectives among its constituent nation-states: "policy coordination, facilities network, unhampered trade, monetary integration and individuals to-individuals bonds." This source gives maybe the most thorough in the general portrayal of the reason behind the One Belt, One Road initiative:

The initiative to mutually assemble the Belt and Road, accepting the pattern towards a multipolar world, economic globalization, social variety and more prominent IT application, is intended to maintain the worldwide deregulation system and the open world economy in the soul of open territorial cooperation. It is pointed toward advancing organized and free progression of economic components, the profoundly effective portion of resources and profound more extensive and more top to bottom provincial cooperation of better expectations; and mutually making an open, comprehensive and adjusted regional economic cooperation architecture that benefits all.

The primary aim of this study addresses the systematic approach to china's strategic plan towards achieving a significant leadership role in world politics under president XI. The paper also aims to enhance the understanding of the BRI and its impact on global politics and the economy. 
The paper would be discussing a brief description of BRI, some key concepts and framework and to bring out the international politics around the BRI and analyse the rise of China as a growing global superpower and how it all depends on the BRI to achieve its aims, and also how it is also a massive threat to the USA's global dominance.

\section{LITERATURE REVIEW}

In one of the state visits of the Chinese President Xi Jinping to Kazakhstan in October 201, Xi unveiled the One Belt One Road initiative which encompassed the Silk Road Economic Belt and the $21^{\text {st }}$ Century Maritime Silk Road (Zeng, 2019). Notwithstanding, Callahan (2016) in his study observed that the concept of the BRI was first proposed by Wang (2012), a well vast IR scholar in Global Times article in October 2012. The author in that article opined that since the USA was prizefighting the People Republic of China to the Maritime East with its Asia pivot, China should muster what is required to march west to expand economic and security ties with its neighbours in Central Asia (Callahan, 2016, p. 11). It was noticed that in November 2014, the Chinese government formally annunciated the establishment of a new Silk Road fund of 40 billion US dollars at the Asia Pacific Economic Cooperation meeting in Beijing, accompanied by the official launching of the project in March 2015 through the National Development and Reform Commission under the Ministry of Foreign Affairs and the Ministry of Commerce (Aoyama, 2016, p. 5). Later on in March 2015, the People's Republic of China government pronounced the Vision and Action and Jointly Building Silk Road Economic Belt and $21^{\text {st }}$ Century Maritime Silk Road, which led to the foundation of the enchanting visionary initiative.

When searched on the official web portal of BRI, the initiative is described as "an initiative originated in China, but a concept that belongs to the world; it is rooted in antiquity, but oriented towards the future and focuses on Asia, Europe, and Africa, but is available to all partners" (PRC, 2019). The project covers numerous countries and regions, and different customs and lifestyles. It, therefore, holds that although this initiative is majorly an infrastructure development project, it has the vision to deliver on social, political, and cultural aspects. BRI comprises 80 countries, mainly from Asia, Europe, and Africa which build up almost $36 \%$ of the global GDP, $68 \%$ of the world's population, and more than $40 \%$ of international trade (Islam, 2019). To highlight the road map of the project, Aoyama (2016) formulated the following table (table 1) to describe six economic corridors and one sea route to be built under this giant initiative.

\section{Table 1: Land and Sea Corridors Consulting Belt and Road Initiative}

1. China-Mongolia-Russia Economic Corridor (CMREC)

It includes two economic corridors. One starts in Northern China, extends through Mongolia and Russia while the other starts in northeast China and reaches Chita (Russia).

2. New Eurasia Land Bridge Economic Corridor (NELBEC)

This route is divided into three parts and connects Liyanyungang province to the port of

Rotterdam in the Netherlands. This corridor can potentially link Japan, South Korea, Iran, Russia, and the EU. 


\section{China-Central Asia-West Asia Economic Corridor (CCAWEC)}

It starts in Xinjiang, Uyghur region and extends through the Persian Gulf, and reaches the coast of the Mediterranean Sea and the Arab Peninsula. It connects Central Asian nations including Kazakhstan, Kyrgyzstan, and Tajikistan as well as Iran and Turkey.

4. China-Indochina Peninsula Economic Corridor (CIPEC)

It starts in Nanning, Guangxi Zhuang Region and Kunming and ends in Singapore. It crosses the South China Sea and faces great difficulties in the establishment.

5. China-Pakistan Economic Corridor (CPEC)

It is a 300-km route connecting Kashgar, Xinjiang, Uyghur region with Gwadar Port in Pakistan. It has the role of connecting 'One Belt' with 'One Road'. An agreement between China and Pakistan to cooperate broadly in areas such as energy, infrastructure, and industry.

6. Bangladesh-China-India-Myanmar Economic Corridor (BCIMEC)

This is to be established together with Bangladesh, India and Myanmar. Through this corridor, China can promote ties with India and Bangladesh, which historically, did not have close ties.

\section{$21^{\text {st }}$ Century Maritime Silk Road}

It consists of routes from the South China Sea and the Indian Ocean to Europe and Africa and routes from the South China Sea to the South Pacific. China plans to invest in 15 international harbour cities as part of this corridor development.

Source: Aoyama, 2016

\section{The Belt on the World Economy}

One Road, on the other hand, called the ground Silk Road, intends to link China mainland means with Central Asia and Europe; while one Belt, which is then again known as Marine Silk Road started from China's Coastal region and countries right to Europe through Southeast Asia and Africa. As indicated by certain discourses by president XI and minister of foreign Affairs Wang YI expressed six entries for the Initiative.

Table 2: Probable participating countries of the initiative

\begin{tabular}{|l|l|l|}
\hline Priority Area & Country/Region & Member Countries \\
\hline 1 & Mid Asia & $\begin{array}{l}\text { Kazakhstan - Kirghizstan - Tajikistan } \\
\text { Turkmenistan - Uzbekistan }\end{array}$ \\
\hline & Russia & $\begin{array}{l}\text { Afghanistan - Bangladesh - India - Maldives } \\
\text { Nepal - Pakistan }\end{array}$ \\
\hline & South Asia & $\begin{array}{l}\text { Brunei - Cambodia -Indonesia - Laos - Malaysia } \\
\text { Myanmar - Philippines - Singapore - Srilanka } \\
\text { Thailand - Vietnam }\end{array}$ \\
\hline & $\begin{array}{l}\text { The Middle East } \\
\text { and East Africa }\end{array}$ & $\begin{array}{l}\text { Egypt - Iran - Iraq - Kuwait - Oman - Qatar } \\
\text { Syria - UAE }\end{array}$ \\
\hline & $\begin{array}{l}\text { Other European } \\
\text { and Africa }\end{array}$ & Benin - Mongolia - Nigeria - Poland - Ukraine \\
\hline
\end{tabular}

Source: Cui et al 2015 
The One Belt One Road is one of the biggest undertakings in world history, the initiative requires a colossal measure of assets. The Chinese have proclaimed from its side USD 40 billion (Chua, 2017). The other funding organization incorporate China investment partnership, send out import bank, China development bank and the state organization of foreign trade, Asian infrastructure investment banks (AIIB) have all assigned their assets in 2015(Sarker et al,2018). The initiative is pointed on the development of infrastructure, economic globalisation, political harmonisation, social trade and reception of advanced technology to accomplish policy cooperation, facilities extemporization, connectivity upgrade, empowering financial integration and making a superior place of living for the mass people (Uberoi, 2016; Haggai, 2016). The Emergence of this initiative would have some vital effects on the world economy which would prompt the following:

i. $\quad$ Better infrastructure for better development: the effect of OBOR will tremendously affect infrastructure and transport developments projects for part nations to arrive at their connectivity goals. With this chance particularly the agricultural countries, it would resuscitate economies and sponsor development and restore their manufacturing area which will result in more positions, lower consumers' costs, and increased investments.

ii. Decreased trade time and costs: the OBOR initiative would allow the world cheaper and quicker transport by the formation of global exchanging routes and overcoming customs checkpoints issues and exchanging hindrances that expands trade time and costs through global assistance arrangements. In an intellectual work, De-soyres et al (2018) argue that OBOR can diminish trade times and costs for taking part countries by $32 \%$. And also expressed on the World Bank portal showed that shipping time is expected to decrease by an average of $1.2 \%$ across all countries in the world.

iii. Increased investment: this would prompt the making of new markets, new organizations and new partnerships eliminating development hindrances and enhancing cooperation. Chen and Lin (2018) paper on the world bank determined that OBOR countries transportation organisations can prompt $4.79 \%$ FDI streams increment, $4.36 \%$ increment with OBOR countries, $4.63 \%$ increment from OECD countries, it likewise anticipated more partnership and more international investment to follow.

iv. Increased trade: the promising impact through economics, global reach and potential competitive markets may bring forth new ventures that could be conceived provincially or conceived globally as per the Uppsala model and business researchers. Konings (2018) covers ING bank determined 4-12\% increment of world trade because of the evacuation of trade hindrances, diminished trade costs and speed up.

v. Increased total national output (GDP): the development of global transportation and effective infrastructure, decrease in trade time and cost, increased international investments will build the economic size, transactions and growth, this would warrant expansion in GDP. 
vi. Power balance: OBOR is improving china with enormous growth, with the multipolar world which incorporates the incredible United States, European Union and China may come to adjust as far as an economic force and military force. It would likewise prompt equilibrium as far as an economic and military power, and would stop struggle in the world. Furthermore, it would end the control of centre nations over the international framework.

vii. Chinese Military grows: It is said that whoever orders the ocean will order world trade and subsequently will order the actual world. About $90 \%$ of the world trade is done via ocean. China is progressively their tactical presence in areas like Djibouti, Pakistan and Sir Lanka Hambantota port. The development is alerting adversaries like the US, Russia, and India. Such activities may trigger global solubilisation, economic shock, financial emergencies, trade wars, and in most pessimistic scenarios Armed struggles.

It is said that China is subjugating African nations, to imperial and neo provincial expansions, but this argument does not describe China-Africa cooperation in the contemporary global system. China needs Africa as Africa needs China, where Africa has trust in China better than it has in the western world (Bráutigam, 2011). In the argument of Hichens (2008), it ought to be noticed that with the exception of Japan, several economies of Asian countries are a lot smaller than China's. Along these lines, China can be profited to be the top supplier of manufactured items to Asia just as the top consumer of agro-products and resources from Asia extraordinarily, South and Central Asia (Andrea, 2014).

\section{Theoretical Framework}

Theories of geopolitics and international affairs have consistently been an indispensable piece of the investigation of global relations. The originator of Geopolitics Halford John Mackinder put his popular yet disputable 'Mackinder's Law' in 1904, as per which, "who controls East Europe, controls Heartland and who controls Heartland, administers the world" (Kelly, 2006). From an international (or political topography) point of view, there are two sorts of forces Land Power and Sea Power. Understanding international affairs concerns the geology of global governmental issues, especially the connection between actual climate (area, assets, and region) and international strategy (Sprout and Sprout, 1960; Tuathail, 1992). International explanations can be depicted as making scenery or setting whereupon global governmental issues happen. To Tuathail (1992), this view is oversimplified.

Kelly (2006) brought up two particular renditions of international affairs - old style and contemporary basic. Traditional hypotheses are a bunch of contemplations by certain researchers, including Rudolf Kjellen, Thayer Mahan, Halford Mackinder, and Karl Haushofer. Tuithail condemns traditional international affairs and promoters for basic international relations, which principally manages statecrafts and thoughts made of pragmatic critical thinking international systems. The investigation of political economy identifies with the comprehension of financial aspects and political theory together. The worldwide political economy manages political relations between various country states in outlining their separate financial arrangements, which has basically been the aftereffect of globalisation and the rise of a quickly coordinated and interconnected world (Timimi, 2010). In International Relations, the states are viewed as individual entertainers who need to amplify their benefit or benefit in serious exchange and monetary ties. 
Traditional market analysts, including Adam Smith and David Ricardo, added to the beginning of the political, monetary arrangement. Nonetheless, the hypothesis has advanced. Presently, Political Economy Analysis (PEA) chiefly centres around the entertainers, organisations, establishments, and their contending advantages as Hall (1997) distinguishes the fundamental helpful segments of a political economy - thoughts, interests, and foundations - to investigate and comprehend the governmental issues inside. The structure created by Pettit and Acosta (2014) clarifies contemporary PEA and distinguishes the meaning of two trademark highlights of PEA. To begin with, the examination of foundations is fundamental in seeing how the social and political establishments shape choices and results and duplicate deviations to secure the interests of persuasive entertainers. In addition, the investigation of people significantly incorporates the wellbeing of people (or a gathering of similar entertainers) which could be material advantages or grants as well as regular great or conduct inside the setting. The total and upper hand of worldwide exchange likewise comes into the examination of the worldwide political economy. Researchers have consolidated the ideas of international relations and global political economy while clarifying the forceful Chinese interests in the Arctic Region, Africa, and Asia (McDonald and Klasche, 2019; Lei, 2018). Luttwak (1990) grounded the beginning of this incorporation of the ideas of international affairs with geo-financial aspects, and contend that understanding the reason for worldwide business and financial aspects requires further experiences of the standards of the game among the players.

McDonald and Klasche (2019), while examining the Chinese journey for assets and control of business foundation around there, stress on understanding the strength of ocean courses and the benefits accompanying it. In the wake of the need for international examination of contemporary geo-financial cycles, Moisio (2017) noticed that this sort of investigation is helpful to clarify the arising between spatial rivalry for provincial and monetary development of worldwide forces. By interfacing these ideas and focal points, this article fosters its examination by checking on appropriate bits of writing and reports of the basic occasions. This paper examines the thoughts, interests and establishments identified with BRI where the individual entertainers and partners are the states and worldwide (respective, multilateral, provincial, and worldwide) foundations with the system of the international examination. Since the paper aims to comprehend worldwide governmental issues in and around Belt and Road advancement projects, this reasonable structure will permit us to investigate the ramifications and learning. The accompanying segments completely present the conversation and investigation drawn from the three ideas - thoughts, interests and establishments - which will lead us to a summed-up show of the contention.

\section{CONCLUSION AND RECOMMENDATIONS}

The One Belt, One Road is an excellent global undertaking for a superior world, the centre standards are exceptionally promising an incredible future where genuine globalisation and integration will advance nations shared advantages and positive trade. On the off chance that this initiative would be a Chinese imperial tool for an expansion in its economic and political powers, at that point that would a major disgrace to the initiative. The OBOR is expected to result in the accomplishment of economic and infrastructural openings for its individuals' countries, particularly by South Asian provinces which would prompt extremely colossal advantages. Also, with the evolutionary projects by China, the One Belt, One Road would in the end significantly affect the global economic affairs and would presumably present a new 
world request in the international system. China should be able to maintain friendly relations with states that signed the Belt and Road agreements as well as those states affected by either the road or the belt through a passage.

\section{REFERENCES}

Acosta, A. M., \& Pettit, J. (2014). Power Above and Below the Waterline: Bridging Political Economy and Power Analysis. IDS Bulletin, 9-22.

AIIB (2016). Asian Infrastructure Investment Bank. Global Governance, 22, 11-26. Available at: http://www.aiib.org/.

Aoyama, R. (2016). One Belt One Road: China's New Global Strategy. Journal of Contemporary East Asia Studies, 3-22.

Bräutigam, D. (2011). Chinese development aid in Africa: What, where, why and how much? In Golley, J. and Ligang, S. (Ed.) Rising China: Global Challenges and Opportunities, Canberra: Australia National University Press, pp. 203-223.

Chen, S. (2017). Regional responses to China's Maritime Silk Road initiative in Southeast Asia. Journal of Contemporary China, 27, 344-361. Available at: https://doi.org/

Cheng, I. K. (2016). Three questions on China's One Belt One Road initiative. China Economic Review, 40, 309-313. Available at: https://doi.org/10.1016/j.chieco.2016.07.008.

Cui, D., Tian, T. and Tai, K. (2015). One Belt \& One Road: Great expectations. Investment Strategy, Bank of America Merrill Lynch. Available at: https://www.uschina.org/sites/default/files/2015.20.203.20

Haggai, K. (2016). One Belt One Road strategy in China and economic development in the concerning countries. World Journal of Social Sciences and Humanities, 2, 10-14

Hitchens (2008). How China has created a new slave empire in Africa. Available at https://www.dailymail.co.uk/news/articlel

Konings, J. (2018). Trade impact of the Belt and Road Initiative.Available at: https://think.ing.com/reports/trade-impacts-of-the-belt-and-road-initiative

Sarker, H.Y. and Sarker, C. (2018). One Belt One Road initiative of China: Implication for Future of Global Development. Modern Economy, 9, 623-638.

Soyres, R. (2018). The Growth and Welfare Effects of the Belt and Road Initiative on East Asia Pacific Countries. MTI Practice Note; no. 4. Washington, D.C.: World Bank Group.

Soyres, R. M., Alen, M. S.; Rocha, G., Nadia, P. R. and Michele, D. (2018). How much will the Belt a d Road Initiative reduce trade costs? Policy Research working paper. No NPS8614 Washington, D.C. world bank Group.

The Peoples' Daily (2014). The initial countries agreed for OBOR. 26 February 2014. Available at: http://www.peoplesdaily.com

Uberoi, P. (2016). Problem and prospects of the BCIM economic corridor.China Report, 52,19-44. Available at: http://doi.org/10.1 